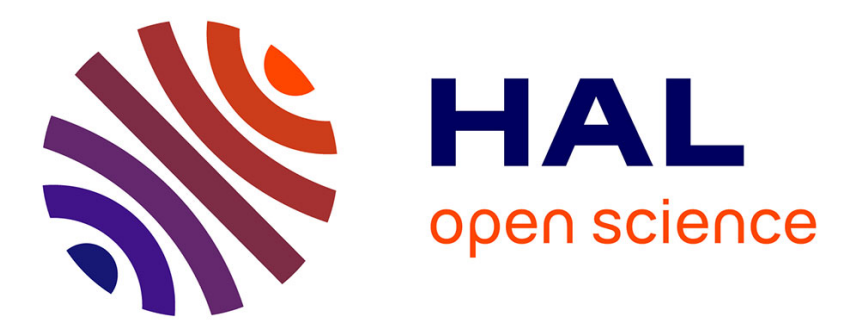

\title{
A new look at left ventricular remodeling definition by cardiac imaging
}

Loïc Bière, Erwan Donal, Alexis Jacquier, Pierre Croisille, Olivier Genée, Luc Christiaens, Fabrice Prunier, Pascal Gueret, Louis Boyer, Alain Furber

\section{- To cite this version:}

Loïc Bière, Erwan Donal, Alexis Jacquier, Pierre Croisille, Olivier Genée, et al.. A new look at left ventricular remodeling definition by cardiac imaging. International Journal of Cardiology, 2016, 209, pp.17-19. 10.1016/j.ijcard.2016.02.009 hal-01272569

HAL Id: hal-01272569

https://hal-univ-rennes1.archives-ouvertes.fr/hal-01272569

Submitted on 11 Feb 2016

HAL is a multi-disciplinary open access archive for the deposit and dissemination of scientific research documents, whether they are published or not. The documents may come from teaching and research institutions in France or abroad, or from public or private research centers.
L'archive ouverte pluridisciplinaire HAL, est destinée au dépôt et à la diffusion de documents scientifiques de niveau recherche, publiés ou non, émanant des établissements d'enseignement et de recherche français ou étrangers, des laboratoires publics ou privés. 


\section{A New Look at Left Ventricular Remodeling definition by Cardiac Imaging}

Loïc Bière ${ }^{\mathrm{a}, \mathrm{b}}$, Erwan Donal c, Alexis Jacquier d, Pierre Croisille e, Olivier Genée ${ }^{\mathrm{f}}$, Luc Christiaens ${ }^{g}$, Fabrice Prunier ${ }^{\mathrm{a}, \mathrm{b}}$, Pascal Gueret ${ }^{\mathrm{h}}$, Louis Boyer ${ }^{\mathrm{i}}$, Alain Furber ${ }^{\mathrm{a}, \mathrm{b}}$

${ }^{a}$ L'UNAM Université, Angers, France

b Université d'Angers, Laboratoire Cardioprotection, Remodelage et Thrombose, UPRES 3860, CHU d'Angers, Service de Cardiologie, Angers, France

c Service de Cardiologie et CIC-IT 804, CHU de Rennes \& Laboratoire Traitement du Signal et de l'Image, INSERM U1099, Rennes, France

${ }^{\mathrm{d}}$ Department of Radiology, Aix Marseille Université, Hôpital Universitaire la Timone, Marseille cedex 05, France

${ }^{\text {e }}$ Hôpital Nord, service de radiologie, CHU de Saint-Étienne, 42055 Saint-Étienne cedex 2, France

${ }^{\mathrm{f}}$ Department of Radiology, University François Rabelais, Tours, France

${ }^{\mathrm{g}}$ Department of Cardiology, University Hospital and Poitiers University, Poitiers, France

${ }^{\mathrm{h}}$ Department of Cardiology, Henri Mondor Hospital and University of Paris Est Créteil, Créteil, France

${ }^{i}$ Pôle Imagerie et Radiologie Interventionnelle CHU de Clermont-Ferrand, ISIT, UMR CNRS 6284 université d'Auvergne Clermont Hospital, Clermont-Ferrand, France

Running title: LV remodeling and imaging

Conflict of interest: the authors declare no conflicts of interest

*Corresponding author:

Loïc Bière, M.D.

Laboratoire Cardioprotection, Remodelage et Thrombose

Faculté de Médecine

Rue Haute de Reculée

F-49045 Angers Cedex 1

Tel.: +33241354858

Fax: +33241354004

Email address: lobiere@chu-angers.fr

Keywords: Left ventricular remodeling, imaging, CMR, echocardiography, myocardial infarction, Cardiac resynchronization therapy 
Left ventricular remodeling (LVR) typically manifests as compensatory changes in ventricular mass, composition, and volume as a response to cardiac performance inadequacy [1]. Cardiac multimodality imaging allows us to investigate both counterparts of remodeling, namely structural and functional remodeling $[2,3]$. Considering the morbi-mortality burden of LVR, these parameters appear to be of value for diagnosing subclinical disease, conducting patient risk stratification, and monitoring response to therapy [1].

We present here a bibliographic survey of multimodality imaging in the assessment of LVR. We sought to identify all trials that described LVR by means of a substantial imaging method.

We identified 264 studies from January 2000 to May 2013 by searching the online Medline electronic database and by manually examining journals and review articles.

Post-myocardial infarction (MI) (175 studies, 66\%) and cardiac resynchronization therapy (CRT) (56 studies, 21\%) were the 2 most commonly studied pathologies. 132 were based on human bedside research. Most (75\%) of the research studies on humans were analytical, whereas 52\% of those involving animals were interventional. Among human researches, the mean population size was 114 \pm 192 patients (median: 54 [25-75 percentiles: 37-103]. The mean time for follow-up assessment varied: $189 \pm 119$ days (median: 180 days [25-75 percentiles: 180-180]) for CRT, and 205 \pm 217 days (median: 180 [25-75 percentiles: 120-180]) for post-MI.

Nowadays, cardiac magnetic resonance (CMR) and transthoracic echocardiography (TTE) are the two principal tools used for volumetric assessment. They present opposite imaging principles of contrast. While contrast in ultrasonography is created by tissue structures, upon which echo waves are reflected, free precession CMR imaging sequences, relays on a T2/T1 contrast, that can 
accentuate the naturally low T1 relaxation time of circulating blood. When combined with partial volume effects inherent of any imaging method, the myocardium may appear mechanically thicker by TTE than by CMR, so that TTE comparatively depicts larger LV mass and smaller volumes [4].

LV volumes and function reproducibility can be affected by the method and type of pathology studied, with still agreements to be lower than 5\% by CMR [3]. Nevertheless, the differences in performance of the various imaging techniques are small.

The bibliographic survey found out that as CMR being incompatible with CRT, LV volumetric parameters were exclusively assessed by TTE $(n=56,100 \%)$ - CMR was eventually confined to pre-therapy assessment of fibrosis - whereas post-MI studies used both CMR ( $\mathrm{n}=71,41 \%)$ and TTE $(n=45,26 \%)$.

Imaging is crucial for the assessment of LV volumes and geometry. Despite the many indices that have been developed to characterize LV shape, LVR is better assessed by global parameters. Above all, LV end-systolic volume (LVESV) present a theoretical advantage, understanding that it combines data on both volumetric assessment and systolic function. White et al. [5] emphasized LVESV as a strong prognostic factor, incremental to LV ejection fraction. Nevertheless, the dichotomous threshold to effectively identify LVR is still debated. In the subset of CRT, a decrease in LVESV, from 10\% [6] to 15\% [7], was related to clinical prognosis and is used in 31 studies. In post-MI patients, LVR was defined in 55 (42\%) studies using a predefined threshold. A $20 \%$ increase in LV end-diastolic volume ( $\mathrm{n}=23$ ) was the most common threshold. Surprisingly, it was never correlated with morbi-mortality, and the citation flow ends with McKay et al. [8]. Published in 1986, invasive LV angiography evaluated LVR between baseline and 14 days in patients treated by thrombolysis. Citation flows were drawn (figure 1 and 2). 
Today, there is a noticeable void in recent prospective studies in the field of post-MI, despite its large prevalence and the continuous advances made in medical management [9]. Associations should be established on homogenous cohorts of patients, robust imaging methods, and long-term cardiac prognosis.

\section{References}

[1] Cohn JN, Ferrari R, Sharpe N. Cardiac remodeling--concepts and clinical implications: a consensus paper from an international forum on cardiac remodeling. Behalf of an International Forum on Cardiac Remodeling. J Am Coll Cardiol. 2000;35:569-82.

[2] Mewton N, Liu CY, Croisille P, Bluemke D, Lima JA. Assessment of myocardial fibrosis with cardiovascular magnetic resonance. J Am Coll Cardiol. 2011;57:891-903.

[3] Grothues F, Smith GC, Moon JC, Bellenger NG, Collins P, Klein HU, et al. Comparison of interstudy reproducibility of cardiovascular magnetic resonance with two-dimensional echocardiography in normal subjects and in patients with heart failure or left ventricular hypertrophy. Am J Cardiol. 2002;90:29-34.

[4] Bellenger NG, Burgess MI, Ray SG, Lahiri A, Coats AJ, Cleland JG, et al. Comparison of left ventricular ejection fraction and volumes in heart failure by echocardiography, radionuclide ventriculography and cardiovascular magnetic resonance; are they interchangeable? European heart journal. 2000;21:1387-96. 
[5] White HD, Norris RM, Brown MA, Brandt PW, Whitlock RM, Wild CJ. Left ventricular endsystolic volume as the major determinant of survival after recovery from myocardial infarction. Circulation. 1987;76:44-51.

[6] Yu CM, Bleeker GB, Fung JW, Schalij MJ, Zhang Q, van der Wall EE, et al. Left ventricular reverse remodeling but not clinical improvement predicts long-term survival after cardiac resynchronization therapy. Circulation. 2005;112:1580-6.

[7] Ypenburg C, van Bommel RJ, Borleffs CJ, Bleeker GB, Boersma E, Schalij MJ, et al. Longterm prognosis after cardiac resynchronization therapy is related to the extent of left ventricular reverse remodeling at midterm follow-up. J Am Coll Cardiol. 2009;53:483-90.

[8] McKay RG, Pfeffer MA, Pasternak RC, Markis JE, Come PC, Nakao S, et al. Left ventricular remodeling after myocardial infarction: a corollary to infarct expansion. Circulation. 1986;74:693-702.

[9] Puymirat E, Simon T, Steg PG, Schiele F, Gueret P, Blanchard D, et al. Association of changes in clinical characteristics and management with improvement in survival among patients with ST-elevation myocardial infarction. JAMA. 2012;308:998-1006. 


\section{Figures}

Figure 1: Citation flow for LV remodeling thresholds in the context of cardiac resynchronization therapy. 10\% (®) and 15\% decrease in LVESV (•) were used in 31 (86\%) threshold-using studies.

Figure 2: Citation flow for LV remodeling thresholds in the context of myocardial infarction. 20\% increase in LVEDV ( $\bullet$ ) and 15\% increase in LVESV ( ) were used in 29 (53\%) thresholdusing studies (see supplementary references). 


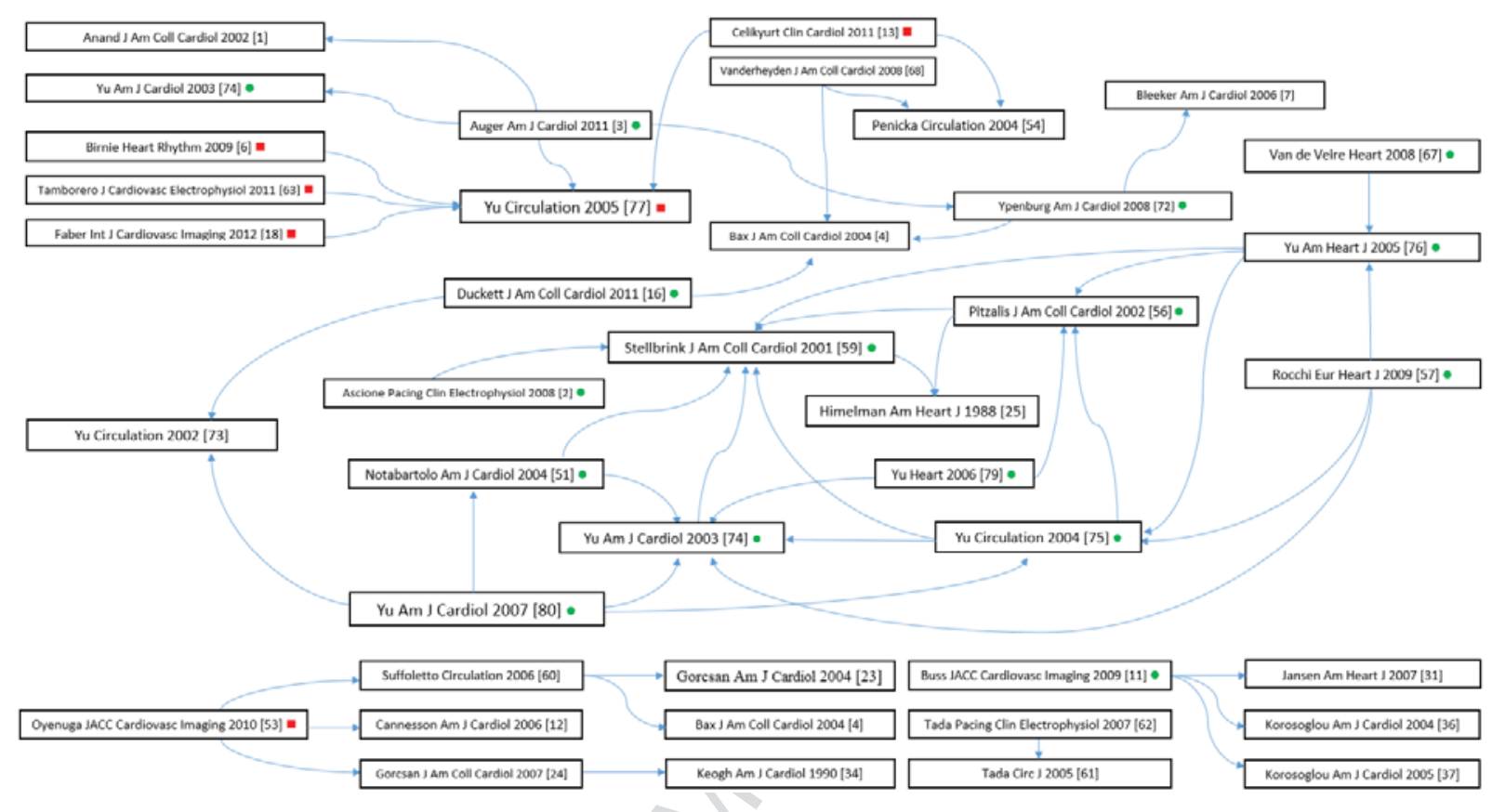

Figure 1 


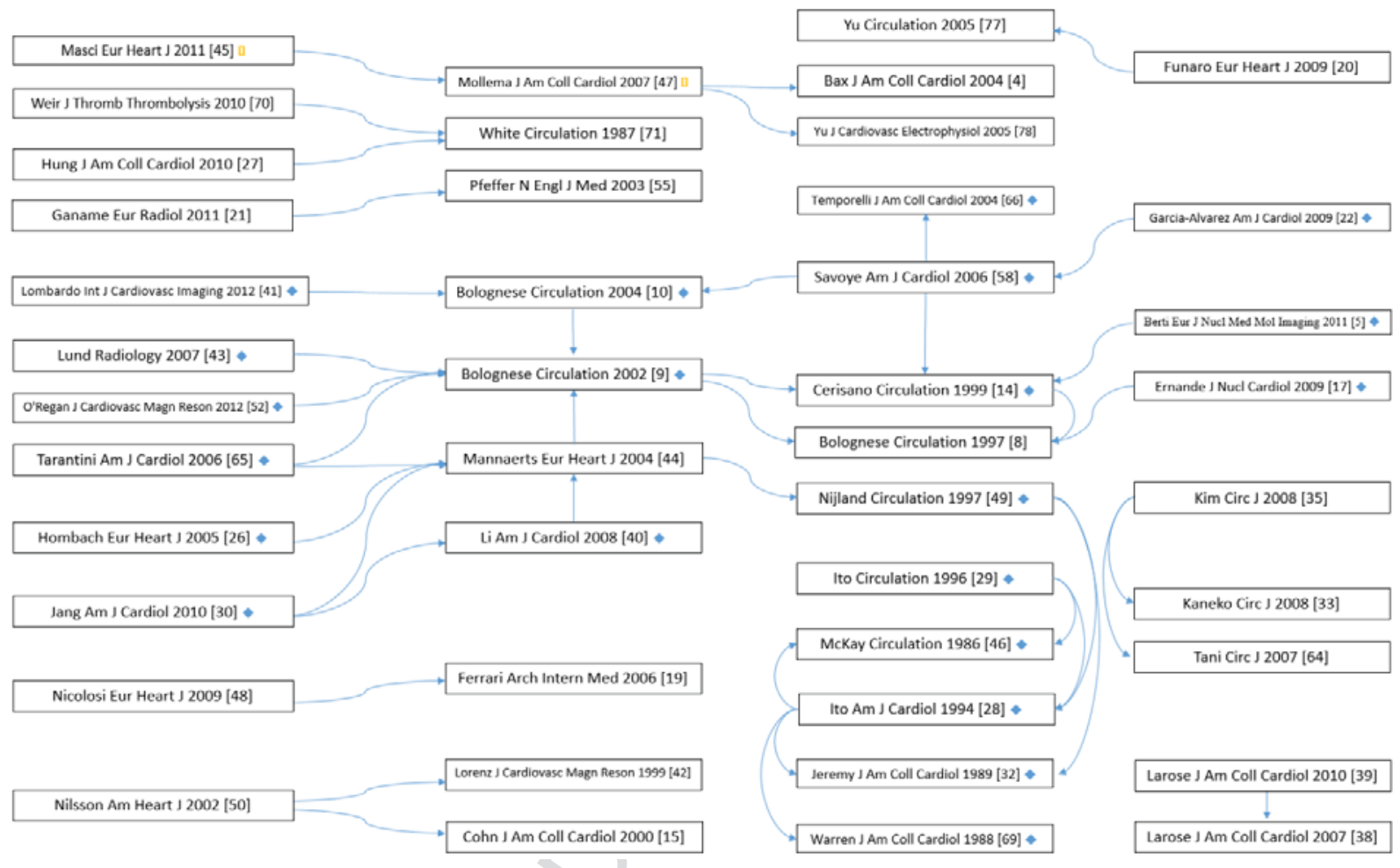

Figure 2 